Copyright (C) 2016 by Academic Publishing House Researcher

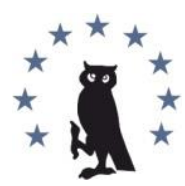

Published in the Russian Federation

European Researcher

Has been issued since 2010.

ISSN 2219-8229

E-ISSN 2224-0136

Vol. 102, Is. 1, pp. 12-24, 2016

DOI: 10.13187/er.2016.102.12

www.erjournal.ru

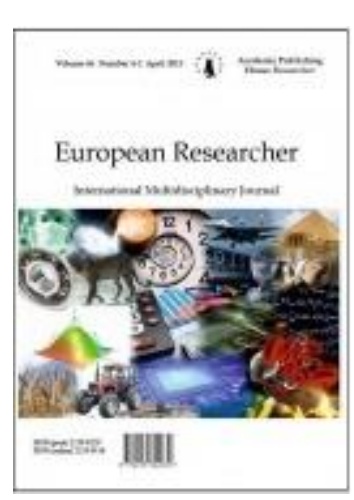

UDC 33

\title{
Human Capital and Economic Development Review of What was Studied and Where was Researched
}

Nereida Hadziahmetovic

International Burch University, Bosnia and Herzegovina

Francuske Revolucije bb, Sarajevo 71000

$\mathrm{PhD}$ candidate, Senior Teaching Assistant

E-mail: nereida.hadziahmetovic@ibu.edu.ba

\begin{abstract}
The main aim of this study is to define the most researched topics and geographical locations and the most active authors and institutions in Human Capital and Economic Development research area. 317 articles that published between 2007 and 2014 from 5 different journals with Social Scientific Citation Index (SSCI) were examined. This study also explores relation between research topics and researched countries and why some topics attracted more attention than others. It is found that some topics and geographic locations were researched more than others. Authors identified topics that were researched less or not researched as well as geographic locations. Proposal for future study is discussed according to results of analysis. location.

Keywords: human capital, economic development, research topics, research geographical

\section{Introduction}

Human Capital plays central role for Economic Development. Lucas (1988) and Romer (1990) brought out the idea that long-term continuous growth could be created by human capital. Mincer (1996) found that during the $2^{\text {th }}$ century human capital development has been impressive. He argues it with: first, progress of education: from small percentages of high school graduates to almost general completion. Second, rise in real income per capita. Third, urbanization: from almost half human forces in agriculture to fewer than $5 \%$. Forth, demographic transition: from high percentage of fertility and mortality to the families with the good health and greater longevity. And, fifth: the trend of woman's contribution in the labor market (Mincer, 1996).

Moreover, according to Mincer (1996) there is a mutual relationship between economic development and human capital growth. Thereby, Mincer (1996) stated that human capital could be involved in economic development as an result of economic growth, not only as a cause of growth process (Mincer, 1996).

According to Schultz, T. W. (1972), the investment in human capital can appropriately be sorted into investment in (1) schooling and higher education, (2) post school training and learning, (3) preschool earning activities, (4) migration, (5) health, (6) information, and (7) investment in children (population) (Schultz, 1972).
\end{abstract}


The main aim of this study is to present an overview picture of what was studied, where studies were conducted and who did the research about the human capital and economic development. This study investigates papers that were published between 2007 and 2014 to define the most studied topics. This study explores relation between research topics and countries where those researches have been conducted and why some topics attracted more attention than others. Furthermore, we analyzed contribution of authors and institutions, and made a network that shows relationship among authors. This study was investigated articles from five Economic Development journals.

This research contributes to the field of Human Capital in a several ways. First, this is unique research, which includes 317 papers published in top journals between 2007 and 2014. It should be noted that papers were published during and after financial crises. Second we identified countries where researches were conducted more frequently and research topics that were focused in those countries. Third, we defined the most active institutions and authors in the field of human capital and economic development.

In the remainder of this paper, methodology was presented and results were briefly explained and discussed. Paper will be completed by giving conclusion after mentioning about limitation and proposal for future research.

\section{Methodology}

This study is based on articles from 5 well known journals with social science citation index (SSCI) in economic development research area.

Name of journals are as follows:

- Economic Development and Cultural Change

- Journal of Economic Growth

- African Development Review

- Journal of Development Economics

- The Economic and Labour Relations Review

Human capital and economic development related articles that were published between 2007 and 2014 have been chosen for analysis. 317 relevant articles were found and necessary information was extracted from those articles. This information consists of title of article, publisher name, journal name, published date, volume, issue, name of authors, keywords, and abstract.

Collected data was analyzed to find the most studied topics, focused countries, the most active authors and institutions in this area.

Content Analysis

8 main variables have been identified using keywords, titles of articles and abstracts. Moreover, sub-variables that belong to those main variables have been defined and how frequent these variables are studied was analyzed.

Research Location Analysis

221 articles out of total 317 articles were focused on specific geographic location. These locations were identified by analyzing abstracts and titles. Later, variables and focus countries were matched to identify which topics are studied the most in which country. In addition to countries, it was also analyzed that which topics are studied the most in which continent. Number of studies for each country was counted as well as for continents.

Authors and Institutions Analysis

Author and institution names are collected from articles to determine which author contributed how many articles and which institution contributed how many articles. This information was used to find the most active authors and institutions. The author list is used to find academic connection between authors. This connection is visualized by drawing coauthorship network graph (Debicki et al., 2009). 


\section{Results}

Authors' Activities

560 different authors have contributed to writing process of 317 articles in 5 different journals between 2007 and 2014. Table 1 shows names of 60 authors who are coauthor of more than one paper. Authors who contributed to only one paper were not included into the list. John C.Anyanwu is published the most among 560 different authors with 5 articles in total 5 different journals. There is only one author who contributed to 5 different articles. There are two authors (David McKenzie, Holger Strulik) who contributed to 4 different articles. 10 authors contributed to 3 papers, 47 authors contributed to 2 articles, the rest 500 authors contributed to only one article.

Table 1: The most published authors

\begin{tabular}{|c|c|}
\hline Name & Count \\
\hline John C. Anyanwu & 5 \\
\hline David McKenzie & 4 \\
\hline Holger Strulik & 4 \\
\hline Belton Fleisher & 3 \\
\hline Çaglar Özden & 3 \\
\hline Damien de Walque & 3 \\
\hline Frédéric Docquier & 3 \\
\hline Harsha Thirumurthy & 3 \\
\hline Jean-Marie Baland & 3 \\
\hline Jere R. Behrman & 3 \\
\hline John Gibson & 3 \\
\hline Xinzheng Shi & 3 \\
\hline Yves Zenou & 3 \\
\hline Amparo Castelló-Climent & 2 \\
\hline Ana C. Dammert & 2 \\
\hline Berk Özler & 2 \\
\hline Cally Ardington & 2 \\
\hline Chad Turner & 2 \\
\hline David de la Croix & 2 \\
\hline David E. Sahn & 2 \\
\hline Djavad Salehi-Isfahani & 2 \\
\hline Duncan Thomas & 2 \\
\hline Emla Fitzsimons & 2 \\
\hline Futoshi Yamauchi & 2 \\
\hline Haizheng Li & 2 \\
\hline Harounan Kazianga & 2 \\
\hline Hillel Rapoport & 2 \\
\hline Iain Campbell & 2 \\
\hline Imran Rasul & 2 \\
\hline Irineu Evangelista de Carvalho Filho & 2 \\
\hline Jakob B. Madsen & 2 \\
\hline Jean-Philippe Platteau & 2 \\
\hline Jesús Fernández-Huertas Moraga & 2 \\
\hline Joshua Graff Zivin & 2 \\
\hline Kathleen Beegle & 2 \\
\hline Kaushik Basu & 2 \\
\hline Kenneth L. Leonard & 2 \\
\hline Kwabena Gyimah-Brempong & 2 \\
\hline Ludger Woessmann & 2 \\
\hline Marcel Fafchamps & 2 \\
\hline
\end{tabular}




\begin{tabular}{|l|l|}
\hline Murray Leibbrandt & 2 \\
\hline Norbert Schady & 2 \\
\hline Pedro Conceição & 2 \\
\hline Peter F. Orazem & 2 \\
\hline Priya Ranjan & 2 \\
\hline Rebecca Thornton & 2 \\
\hline Richard Akresh & 2 \\
\hline Robert Tamura & 2 \\
\hline Simone Bertoli & 2 \\
\hline Sanghamitra Das & 2 \\
\hline Sean E. Mulholland & 2 \\
\hline Sebastian Galiani & 2 \\
\hline Sebnem Kalemli-Ozcan & 2 \\
\hline Seonghoon Kim & 2 \\
\hline Steven Stillman & 2 \\
\hline Una Okonkwo Osili & 2 \\
\hline Vladimir Ponczek & 2 \\
\hline Xiao-yuan Dong & 2 \\
\hline Yasuyuki Sawada & 2 \\
\hline Zaki Wahhaj & 2 \\
\hline
\end{tabular}

Institutions' Activities

Authors of 317 articles are supported by 323 different institutions. Table 2 presents number of articles that each institution supported. Table 2 shows institutions that supported more than 4 articles. There are 20 institutions that supported 3 different articles, 55 institutions that supported 2 different articles and 218 institutions that supported only one article. It should be noted that institutions are counted per article. When 2 or more authors are supported by same institution in the same article, that institution is counted only ones. Moreover, if an author is supported by 2 or more different institutions, all institutions are included. The Word Bank was the most active institution by supporting 35 different articles.

Table 2: The most active institutions

\begin{tabular}{|l|c|}
\hline Institution Name & Count \\
\hline World Bank & 35 \\
\hline National Bureau of Economic Research, USA & 16 \\
\hline University of California & 15 \\
\hline Institute for the Study of Labor, Germany; & 14 \\
\hline Harvard University & 10 \\
\hline Université Catholique de Louvain & 9 \\
\hline Centre for Economic Policy Research, UK & 8 \\
\hline CES-Ifo, Germany; & 8 \\
\hline African Development Bank & 7 \\
\hline International Food Policy Research Institute, USA; & 7 \\
\hline Stanford University & 7 \\
\hline University of Maryland & 7 \\
\hline University of Michigan & 7 \\
\hline University of Oxford & 7 \\
\hline Inter-American Development Bank & 5 \\
\hline
\end{tabular}




\begin{tabular}{|l|c|}
\hline Ohio State University & 5 \\
\hline University College London & 5 \\
\hline University of Cape Town & 5 \\
\hline University of Namur & 5 \\
\hline Brown University & 4 \\
\hline Cornell University & 4 \\
\hline Duke University; & 4 \\
\hline Institute for Fiscal Studies, UK & 4 \\
\hline International Monetary Fund & 4 \\
\hline London School of Economics & 4 \\
\hline Monash University & 4 \\
\hline University of Copenhagen & 4 \\
\hline University of North Carolina & 4 \\
\hline University of Pennsylvania & 4 \\
\hline University of Auvergne & 4 \\
\hline
\end{tabular}

Coauthors Connection Analysis

Figure 1 presents authors who are coauthors of 2 or more articles and their academic connection with other authors. Each author who is coauthors of 2 or more articles is presented by a black dot in the graph. If two authors participated in same two or more articles, they are connected by a line. For instance, John C.Anyanwu is coauthor of 5 different articles and he is presented by a dot. Both Jean-Marie Baland and Fernanda Estevan are coauthors of 2 or more articles and both of them are coauthors in the same 2 or more articles. They are presented by dot and their coauthorship is presented by a line between. Another example can be a triangle relationship between David Mckenzie, Steven Stillman and John Gibson. They all have contributed to more than two articles and Mckenzie and Stillman contributed to same 2 or more articles as well as Mckenzie and Gibson or Stillman and Gibson.

Topic Analysis

Topic analysis aims to show focuses on certain topics. Topic of each article is determined and named as subvariable. Similar subvariables are combined to define main variables. Main variables of the articles are as follows: Health System (16.7\%), Education System (17\%), Migration (15.8\%), Labor Market (17.7\%), Gender Gap (8.2\%), Population Growth (11.4\%), Inequality and Poverty (3.8\%), and Human Capital (9.5\%). Health System, Education System, Migration, and Labor Market are the topics that were the most attractive topics.

In Labor Market related articles, it is found that the topic, Child Labor, is the most studied topic with 34\%. Furthermore, Labor Market and Employment comprises 12\%, comparing with Labor Market and Unemployment which were studied only 5\%. On the other side, Labor Market and Economic Crises topic comprises only $2 \%$, which was unexpectable due to chosen time period (2007 to 2014) of this research.

In Education System related articles, it is found that the topic, Education and Economic Growth is the most studied topic with 44\%. Education and Inequality is studied the second most with 9\%. Fertility and Parental Participation topics comprise $7 \%$ each. Other topics comprise less than $7 \%$ each and surprisingly, Education Distribution topic takes only $2 \%$.

Migration related studies are also one of main topics in this research with $15.8 \%$ of all articles. It is found that the most studied topic in this area is Migration and Economic Development with $36 \%$. Brain Drain is the second most studied topic with $22 \%$. Topics Remittance and Temporary Labor Migration take $8 \%$ each. On the other hand, Illegal Migration takes only $2 \%$.

Another main study area is Health System with $16.7 \%$. AIDS is the most studied topic with $24 \%$, then Nutrition with $21 \%$ and Health and Economic Growth with 19\%. Malaria and Health Expenditures were studied with 6\% each. 

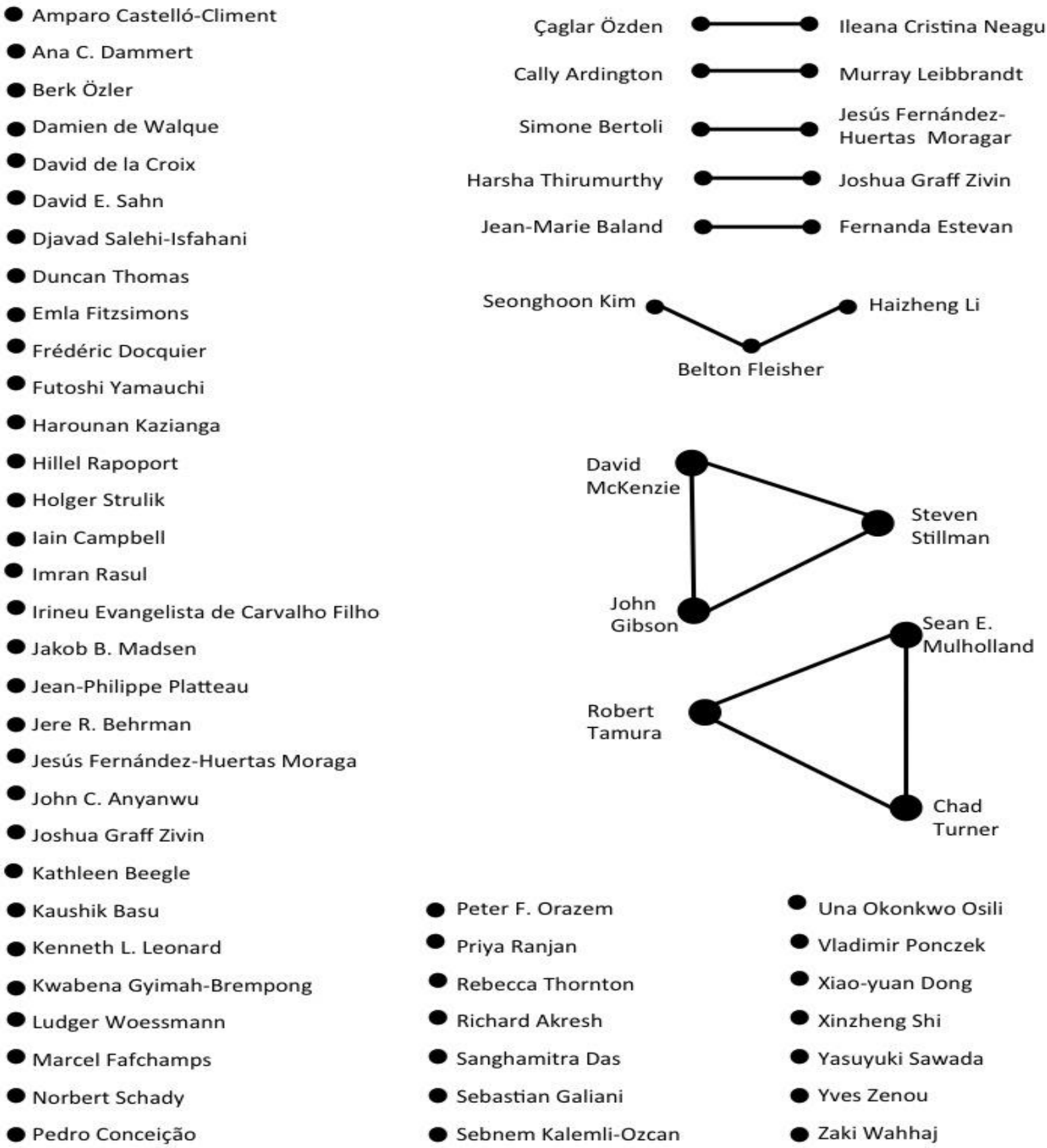

Figure 1 Coauthorship Connection Analysis (Two or More Publications per Author)

$11 \%$ of studies were about Population Growth. $45 \%$ of Population Growth studies were focused on Family related topics. Furthermore, Mortality takes $22 \%$ and Fertility takes $11 \%$.

All main and subvariables were presented in

Table 3. The most left column presents main variables and the second left presents subvariables which belong to one of main variable. Article count column shows how many articles focused on that specific main and subvariable. Percentage in Group column is amount of studied about subtopic respect to all studied in main topic group. Percentage in Total column shows how much percentage of all studies is dedicated for certain main or subtopic. 
Table 3: Main and subvariables and their distribution

\begin{tabular}{|c|c|c|c|c|}
\hline Main Variable & Subvariable & $\begin{array}{l}\text { Article } \\
\text { Count }\end{array}$ & $\begin{array}{l}\text { Percentage } \\
\text { in Group }\end{array}$ & $\begin{array}{l}\text { Percentage } \\
\text { in Total }\end{array}$ \\
\hline \multirow{12}{*}{ Health System } & & 53 & & 16.7 \\
\hline & Health and Economic Growth & 10 & 18.9 & 3.2 \\
\hline & Nutrition & 11 & 20.8 & 3.5 \\
\hline & Child Health & 3 & $5 \cdot 7$ & 0.9 \\
\hline & AIDS & 13 & 24.5 & 4.1 \\
\hline & Epidemics & 1 & 1.9 & 0.3 \\
\hline & Malaria & 3 & 5.7 & 0.9 \\
\hline & Health and Productivity & 2 & 3.8 & 0.6 \\
\hline & Health Expenditure & 3 & 5.7 & 0.9 \\
\hline & Health Inequality & 4 & $7 \cdot 5$ & 1.3 \\
\hline & Education in Health Care & 1 & 1.9 & 0.3 \\
\hline & Health Systems and Fertility & 2 & 3.8 & 0.6 \\
\hline \multirow[t]{14}{*}{ Education System } & & 54 & & 17 \\
\hline & Education and Economic Growth & 24 & 44.4 & 7.6 \\
\hline & Education and Expenditure & 3 & 5.6 & 0.9 \\
\hline & Education and Fertility & 4 & 7.4 & 1.3 \\
\hline & Education and Health & 2 & 3.7 & 0.6 \\
\hline & Education and Income & 3 & 5.6 & 0.9 \\
\hline & Education and Inequality & 5 & 9.3 & 1.6 \\
\hline & Education Distribution & 1 & 1.9 & 0.3 \\
\hline & Education and Parental & & & \\
\hline & Participation & 4 & 7.4 & 1.3 \\
\hline & Education and Public Schools & 3 & 5.6 & 0.9 \\
\hline & Education and Cash Transfer & & & \\
\hline & Program & 3 & 5.6 & 0.9 \\
\hline & Women's Education & 2 & 3.7 & 0.6 \\
\hline \multirow[t]{11}{*}{ Migration } & & 50 & & 15.8 \\
\hline & Migration and economic & & & \\
\hline & development & 18 & 36 & $5 \cdot 7$ \\
\hline & Migration and brain drain & $\begin{array}{c}11 \\
2\end{array}$ & $\begin{array}{c}22 \\
4\end{array}$ & $\begin{array}{l}3.5 \\
0.6\end{array}$ \\
\hline & Migration and Investment & 2 & $\begin{array}{l}4 \\
4\end{array}$ & 0.6 \\
\hline & Migration and wages & 3 & 6 & 0.9 \\
\hline & Illegal Migration & 1 & 2 & 0.3 \\
\hline & Temporary Labor Migration & 4 & 8 & 1.3 \\
\hline & Internal Migration & 2 & 4 & 0.6 \\
\hline & Migrations and Inequality & 3 & 6 & 0.9 \\
\hline & Migrations and remittances & 4 & 8 & 1.3 \\
\hline \multirow[t]{11}{*}{ Labor Market } & & 56 & & 17.7 \\
\hline & Labor Market and Economic & & & \\
\hline & Development & 10 & 17.9 & 3.2 \\
\hline & Labor Market and Civil War & 3 & $5 \cdot 4$ & 0.9 \\
\hline & labor market and employment & 7 & 12.5 & 2.2 \\
\hline & labor market and investment & 1 & 1.8 & 0.3 \\
\hline & Labor Market and Poverty & 1 & 1.8 & 0.3 \\
\hline & Labor Market and regulations & 4 & 7.1 & 1.3 \\
\hline & Labor market and unemployment & 3 & 5.4 & 0.9 \\
\hline & Labor Market and Discrimination & 1 & 1.8 & 0.3 \\
\hline & Labor Market Youth Employment & 2 & 3.6 & 0.6 \\
\hline
\end{tabular}


Child Labor

Labor Market and Economic Crisis

Women's Labor and Motherhood
33.9

1.8

7.1

6

0.3

1.3

8.2

Gender and Income

gender difference in education

gender empowerment

Gender Inequality

Gender-Caste development

Gender and employment

Labor Market and Gender

Women's Right

\begin{tabular}{ll} 
Population Growth & \\
\hline & Family and Economic Growth \\
& Population Growth \\
& Mortality \\
& Fertility
\end{tabular}

\begin{tabular}{llccc}
$\begin{array}{l}\text { Inequality and } \\
\text { Poverty }\end{array}$ & & & & \\
& & 12 & & 3.8 \\
\hline Human Capital & Poverty & 10 & 83.3 & 3.2 \\
& Inequality of nations & 2 & 16.7 & 0.6 \\
\hline & & 30 & & 9.5 \\
& Human Capital and Economic & & & \\
& Growth & 13 & 43.3 & 4.1 \\
& human capital and civil war & 1 & 3.3 & 0.3 \\
& Human Capital and Human Rights & 1 & 3.3 & 0.3 \\
& Share of Wages & 6 & 20 & 1.9 \\
& Income & 2 & 6.7 & 0.6 \\
& Social Security & 4 & 13.3 & 1.3 \\
& Pension & 3 & 10 & 0.9
\end{tabular}

Researched Country Analysis

221 of 317 total articles focus on a specific geographical region or country. Each article which targets a specific location is labeled with country name and study topic. Table 4 displays the number studies that targeted a continent in main research topics. Since the list of countries is too long, our discussion here is given in continent level.

The most studied continent is Africa with 88 articles (40\%). The second most studied continent is Asia with 69 articles (32\%). Central and South America is studied in 47 different articles (21\%). Table 5, Table 6, Table 7, Table 8, Table 9, and Table 10 presents countries and number of studies that researched that country.

Results show that the most studied topic in Africa is Health System (32\%) and then Labor Market (18\%) as a second and Education System (15\%) as a third most studied topic among articles related to Africa continent.

In Asia continent, focus of studies moves to Education System and Health System with 21\% each. Gender Gap and Labor Market comprise 13\% of research while Population Growth and Migration comprise $10 \%$ and $9 \%$ respectively.

Big part of researches in Central and South America focuses on Labor Market. 34\% of studies focuses on Labor Market while 21\% on Migration, 11\% on Health System.

North America, Europa, and Australia are, as expected, less studied continents since most of countries from these continents are well developed countries. 
In country level, China and India are the most studied countries with 16 articles each (14\% of all countries in total). Mexico has been studied in 15 articles while South Africa in 13 and Brazil in 11 articles.

Table 4: Topic distribution over continents

\begin{tabular}{|c|c|c|c|c|c|c|c|c|}
\hline & 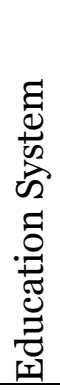 & 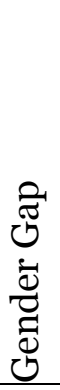 & 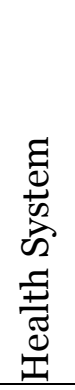 & 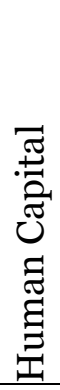 & 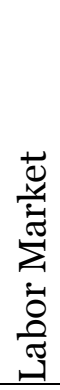 & 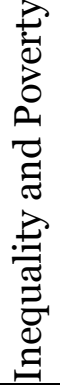 & 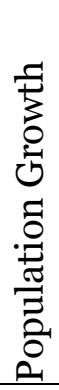 & 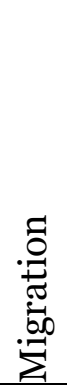 \\
\hline Africa & 13 & 6 & 29 & 9 & 16 & 5 & 9 & 1 \\
\hline Asia & 15 & 9 & 14 & 5 & 9 & 4 & 7 & 6 \\
\hline Central and South America & 10 & & 5 & 4 & 15 & 1 & 3 & 9 \\
\hline North America & 1 & & & 1 & & & & 4 \\
\hline Europa & 1 & & & & 2 & & 2 & 1 \\
\hline Australia & 1 & 2 & & & 1 & & 1 & 1 \\
\hline
\end{tabular}

Table 5: Studied countries in Africa continent

\begin{tabular}{|l|c|}
\hline Africa & 88 articles \\
\hline South Africa & 13 \\
\hline Africa & 10 \\
\hline Kenya & 6 \\
\hline Nigeria & 6 \\
\hline Tanzania & 6 \\
\hline Sub-Saharan Africa & 5 \\
\hline Uganda & 5 \\
\hline Ghana & 4 \\
\hline Malawi & 5 \\
\hline Cote d'Ivoire & 3 \\
\hline Ethiopia & 3 \\
\hline Burkina Faso & 2 \\
\hline Cameroon & 2 \\
\hline Lesotho & 2 \\
\hline Madagascar & 2 \\
\hline Senegal & 2 \\
\hline Sudan & 2 \\
\hline Arab Countries & 1 \\
\hline Egypt & 1 \\
\hline Eritrea & 1 \\
\hline Botswana & 1 \\
\hline Mali & 1 \\
\hline Morocco & 1 \\
\hline Mozambique & 1 \\
\hline Rwanda & 1 \\
\hline Swaziland & 1 \\
\hline West Africa & 1 \\
\hline Zambia & 1 \\
\hline Zimbabwe & 1 \\
\hline
\end{tabular}


Table 6: Studied countries in Europa continent

\begin{tabular}{|l|c|}
\hline Europa & 6 articles \\
\hline Turkey & 3 \\
\hline UK & 2 \\
\hline BiH & 1 \\
\hline
\end{tabular}

Table 7: Studied countries in Asia continent

\begin{tabular}{|l|c|}
\hline Asia & 69 \\
\hline China & 16 \\
\hline India & 16 \\
\hline Indonesia & 9 \\
\hline Bangladesh & 3 \\
\hline Pakistan & 3 \\
\hline Philippines & 3 \\
\hline South Korea & 3 \\
\hline Vietnam & 3 \\
\hline Iran & 2 \\
\hline Taiwan & 2 \\
\hline Cambodia & 1 \\
\hline Himalayas & 1 \\
\hline Japan & 1 \\
\hline Malaysia & 1 \\
\hline Nepal & 1 \\
\hline South Asia & 1 \\
\hline Sri Lanka & 1 \\
\hline Tajikistan & 1 \\
\hline Israeli & 1 \\
\hline
\end{tabular}

Table 8: Studied countries in Central and South America

\begin{tabular}{|l|c|}
\hline Central and South America & 47 articles \\
\hline Mexico & 15 \\
\hline Brazil & 11 \\
\hline Colombia & 6 \\
\hline Latin America & 5 \\
\hline Peru & 3 \\
\hline Argentina & 2 \\
\hline Ecuador & 1 \\
\hline El Salvador & 1 \\
\hline Guatemala & 1 \\
\hline Nicaragua & 1 \\
\hline Venezuela & 1 \\
\hline
\end{tabular}

Table 9: Studied countries in North America

\begin{tabular}{|l|c|}
\hline North America & 7 \\
\hline United States & 7 \\
\hline
\end{tabular}

Table 10: Studied countries in Australia

\begin{tabular}{|l|l|}
\hline Australia & 6 \\
\hline Australia & 6 \\
\hline
\end{tabular}




\section{Discussion}

This study has investigated 317 articles from 5 different economic development related journals among SSCI journals. The main aim of this study was to identify the most studied topics, the most studied countries, the most active authors and institutions in reseach field of economic development and human capital from 2007 to 2014. 560 different authors from 323 different institutions have contributed to writing process of 317 articles. 221 of these articles were dedicated to some country or geographic location. Articles are categorized under 8 main topics. Results of analysis show that the topics Labor Market, Education System, and Health Systema are the most studied topics and the most studied subtopics are Education and Economic Development, Child Labor, Migration, and Family and economic Development. Moreover, it is also found that in a continent level, Africa continent is the most studied continent and in a country level, China, India, Mexico and South Africa are the most studied countries.

Author and institution analysis has shown that huge number of authors from huge number of different institution are conducting researches on Human Capital and Economic Development. Coauthorship connection analysis has shown that studies are not centralized, that is, studies and authors are distributed to different locations and institutions.

Health System is one of the most studied topic with $16.7 \%$ of all articles. Among subtopics in Health System, AIDS is the most studied subtopic with $4.1 \%$ then Nutrition follows with $3.5 \%$. However, Health Expenditure was studied only 0.9\%. Health System was studied the most in Africa continent with $13.1 \%$, then in Asia with 6.3\%. In Central and South America, studies about Health System comprises only $2.3 \%$ of all studies. No study has found on Health Study in Europa, North America, and Australia contenents.

Education System is studied mostly in Asia with 6.3\% and in Africa with 5.9\%. In Central and South America, Education System related topics comprises $4.5 \%$ of all studies. It is found that about North America, there is only one article published related to Education System, and this article studied education and income of states of the United States using data collected between 1840 and 2000 (Turner et al., 2007). Also about Australia, only one article was published by Gerry Redmond (2009). Redmond studied Australian childeren's right to develop to their fullest capacity (Redmond, 2009). About Education System in Europa, only article from Murat Kirdar researched about ethnic disparities in school enrollment using data collected from Turkey (Kirdar, 2007).

Labor Market is the most studied topic with 17.7\%. In Africa and Central and South America, topic is studied $7.2 \%$ and $6.8 \%$, respectively. For Asia, study percentage is 4.1 . The most studied topic in this area is Child Labor with 6\%. In addition to Child Labor, Women's Labor, Labor Market and Employment, Labor Market and Regulations are also among studied topics. Moreover, there is only 2 articles about Youth Employment in Labor Market. John C. Anyanwu studied characteristics and macroeconomic determinants of youth employment in Africa (Anyanwu, 2013). One of the two articles about Labor Market in Europa is article about conflict displacement and labor market outcomes in post-war Bosnia and Herzegovina(Kondylis, 2010). Other study about Labor Market in Europa is article which explores the impacts of 2008-2009 economic crisis on joblesness in Turkey(Bahçe and Memiş, 2014).

Migration is mostly studied in Central and South America contenent. The percentage of migration related studies in Central and South America to all studies is 4.1\%. Then percentages of studies in Asia and North America are 2.7\% and 1.8\%, respectively. In each of Africa, Europa, and Australia contenent, only one study is published about Migration. The article from Africa analyses data from Nigerian villeage to compare success between villeagers who left and who stayed (Onyeiwu et al., 2008). Boese, Campbell, Roberts, and Tham (2013) investigated temporary migration of nurses to Australia and their adaptation to Australian health system (Boese et al., 2013). Furthermore, Ali Berker is author of the only article from Europa among our researched articles. He investigated the labor market consequences of internal migration using data from 1990 and 2000 censuses in Turkey (Berker, 2011). The country where migration is studied the most is Mexico with 8 articles. Among papers related to migration in Mexico, Manuela Angelucci (2012) investigated the effect of US border policy on Mexican illegal migration (Angelucci, 2012). Moreover, this is the only article which studies illegal migration.

Gender Gap with $8.2 \%$, Inequality and Poverty with 3.8\%, and Population Growth with $11.4 \%$ are among less studied topics. Gender Gap is mostly studied in Asia with $4.1 \%$, Inequality and Poverty in Africa with 2.3, and Population Growth in Africa with 4.1\%. 
According to our analysis of geographical locations and to topics, number of articles for some specific locations and topics appear very low. As expected, it is found that studies focus more on developing countries than on developed countries. From other side there are still many developing countries which could be focus of research in human capital and economic development. For instance, there is only one study that investigated Southeastern. However, transitions countries in Southeastern Europe such as Albania, Bosnia and Herzegovina, Macedonia, Serbia, and Kosovo can be researched more.

It is also found that there are topics which were not studied at all or sufficient. For instance, there is only one article about migration in Africa despite civil wars, health and education problems. Illegal migration also could be studied more. Moreover, Health and Education Expenditures did not take sufficient interest as well as Education Distribution. Furthuremore, there is a need to research more on Youth Employment and Unemployment. Unexpectably, it appears that effects of economic crisis on main topics of our research were not investigated enough despite this study examines period of economic crises and post economic crises.

\section{Limitations}

This study identifies the most researched topics in Human Capital and Economic Development research area in 5 different journals from 2007 to 2014. It also identifies the most studied geographic locations as well as the most active authors and institutions. Our method to evaluate individual and institutional contributions is adapted from earlier approaches in entrepreneurship (Shane, 1997) and family business (Debicki et al., 2009). However, several limitations exist in this study. First, even if we have investigated 317 articles which can be considered as a big enough article pool, number of journal that were examined is 5 . More journals can be included to obtain more precise results. Moreover, each of 8 main topics can be investigated separately using the same approach with this study. Second, this study is also limited to last 7 years. Third, the results of our research are affected by the journals we chose to examine. Our focus was on economic development related journal with SSCI.

Based on our analysis, it is noted that several topics have not been researched enough as well as some geographic locations. These topics and locations have potential to be future study topic.

\section{Conclusion}

317 articles were explored in order to identify the most studied topic and geographical location and the most active authors and institutions. It was found that Health System, Education System, Labor Market and Migration are the most studied topics where Education and Economic Development, Child Labor, Migration, Brain Drain and Family and Economic Development are the most studied subtopics. Moreover, China, India, Mexico, South Africa and Brazil are the most researched countries. In continent level, Africa is found as the most researched continent. 560 authors from 323 different institutions has particapated in writing these 317 articles. Author and institution analysis showed that studies are not centrilized around certain group of institutions and authors, by contrast, researchs are distributed all over the world. Research topics focus mostly on devoloping countries, however, it is found that locations of research are mostly from developed countries. Results of our analysis identified that some topics have potential to be researched extendedly such as migration in Africa, illegal migration in general, Health and Education Expenditures, Education Distribution, and Youth Employment.

\section{References:}

1. Angelucci, M., 2012. US Border Enforcement and the Net Flow of Mexican Illegal Migration. Econ. Dev. Cult. Change 6o, 311-357.

2. Anyanwu, J.C., 2013. Characteristics and Macroeconomic Determinants of Youth Employment in Africa: Youth Employment in Africa. Afr. Dev. Rev. 25, 107-129. doi:10.1111/j.1467-8268.2013.12019.x

3. Bahçe, S.A.K., Memiş, E., 2014. The impact of the economic crisis on joblessness in Turkey. Econ. Labour Relat. Rev. 25, 130-153. doi:10.1177/1035304613519380

4. Berker, A., 2011. Labor-Market Consequences of Internal Migration in Turkey. Econ. Dev. Cult. Change 60, 197-197. doi:10.1086/661217 
5. Boese, M., Campbell, I., Roberts, W., Tham, J.-C., 2013. Temporary migrant nurses in Australia: Sites and sources of precariousness. Econ. Labour Relat. Rev. 24, 316-339. doi:10.1177/1035304613496500

6. Debicki, B.J., Matherne, C.F., Kellermanns, F.W., Chrisman, J.J., 2009. Family Business Research in the New Millennium: An Overview of the Who, the Where, the What, and the Why. Fam. Bus. Rev. 22, 151-166. doi:10.1177/0894486509333598

7. Kirdar, M., 2007. Explaining Ethnic Disparities in School Enrollment in Turkey (MPRA Paper No. 2649). University Library of Munich, Germany.

8. Kondylis, F., 2010. Conflict displacement and labor market outcomes in post-war Bosnia and Herzegovina. J. Dev. Econ. 93, 235-248. doi:10.1016/j.jdeveco.2009.10.004

9. Mincer, J., 1996. Economic development, growth of human capital, and the dynamics of the wage structure. J. Econ. Growth 1, 29-48. doi:10.1007/BFoo163341

10. Onyeiwu, S., Iorgulescu Polimeni, R., Polimeni, J.M., 2008. Distributional Impact of Globalization-induced Migration: Evidence from a Nigerian Village. Afr. Dev. Rev. 20, 115-134. doi:10.1111/j.1467-8268.2008.00179.x

11. Redmond, G., 2009. What Can Data on Educational Outcomes Reveal regarding Australian Children's Right to Develop "to Their Fullest Potential”? Econ. Labour Relat. Rev. 20, 35-58. doi:10.1177/103530460902000104

12. Schultz, T.W., 1972. Human Capital: Policy Issues And Research Opportunities, in: Economic Research: Retrospect and Prospect Vol 6: Human Resources. UMI, pp. 1-84.

13. Shane, S.A., 1997. Who is Publishing the Entrepreneurship Research? J. Manag. 23, 8395. doi:10.1177/014920639702300105

14. Turner, C., Tamura, R., Mulholland, S.E., Baier, S., 2007. Education and income of the states of the United States: 1840-2000. J. Econ. Growth 12, 101-158. doi:10.1007/s10887-0079016-0

УДК 33

\section{Человеческий капитал и экономическое развитие. Обзор того, что и где было изучено}

Нерида Хадзиахметович

Международный университет Бёрч, Босния и Герцеговина $\mathrm{PhD}$

E-mail: nereida.hadziahmetovic@ibu.edu.ba

Аннотация. Основная цель данного исследования является определение наиболее исследуемых тем и географических местоположений наиболее активных авторов и учреждений в области исследований человеческого капитала и экономического развития. Были рассмотрены 317 статей, которые опубликованы в период между 2007 и 2014 гг. в 5 различных журналах, включенных Social Scientific Citation Index (SSCI). Это исследование также рассматривает отношения между научно-исследовательскими темами и исследуемыми странами, и почему некоторые темы привлекают больше внимания, чем другие. Автор обнаружил, что некоторые темы и географические места были исследованы в большей степени, чем другие. Авторы определили темы, которые были исследованы меньше или не исследуются, а также их географические местоположения.

Ключевые слова: человеческий капитал, экономическое развитие, научноисследовательские темы, исследование географического расположения. 